International Review of Social History 45 (2000), pp. II5-I35

(C) 2000 Internationaal Instituut voor Sociale Geschiedenis

\title{
Industrious Households: Survival Strategies of Artisans in a Southwest German Town during the Eighteenth and Early Nineteenth Centuries*
}

\author{
DENNIS A. FREY, JR
}

In the last two decades, scholars have significantly expanded, through the use of probate inventories, our purview of early-modern European households. Their work has tended to focus on the social and cultural implications of the material culture found in these inventories. ${ }^{1}$ Seldom, however, have they used these sources to study the family economy found in many early-modern European households, and since artisanal small-scale production remained the predominant mode of urban economic activity, this has produced a conspicuous gap in our knowledge. ${ }^{2}$ This essay, which contains a comprehensive investigation of probate inventories from artisanal households during the eighteenth and early nineteenth centuries, is a modest attempt to fill some of that gap by providing a more nuanced understanding of the social, cultural, and economic survival strategies employed by the

* The Fulbright Commission and the Daimler-Benz-Stiftung provided generous assistance that facilitated the research for this paper, and the insightful and thought-provoking criticisms of Frederick Marquardt served this essay well. I extend my heartfelt gratitude to them. Any faults herein are my own.

I. Among many diverse studies, see the following: Anja R. Benscheidt, Kleinbürgerlicher Besitz: Nürtinger Handwerker-inventare von I660 bis I840 (Münster, 1985); Cissie Fairchilds, "The Production and Marketing of Populuxe Goods in Eighteenth-Century Paris”, in John Brewer and Roy Porter (eds), Consumption and the World of Goods (London, 1993), pp. 228-248; Andrea Hauser, Dinge des Alltags: Studien zur historischen Sachkultur eines schwäbischen Dorfes (Tübingen, 1994); Peter Höher, "Konstanz und Wandel in Wohnausstattung und Hauswirt-schaft (16301899): Das Beispiel Nürtingen am Neckar”, in Günter Wiegelmann (ed.), Beiträge zur Volkskultur in Nordwestdeutschland s5 (Münster, 1987), pp. 309-331; Barbara Knüttel, Manns- und Weibskleider in Unterfranken (Würzburg, 1983); Uwe Meiners, "Zur Wohnkultur der münsterschen Bevölkerung in der zweiten Hälfte des 18. Jahrhunderts: Eine Fallstudie anhand von Nachlaßverzeichnissen", in Rheinisch-westfalische Zeitschrift für Volkskunde, 25 (1979/80), pp. 80-103; Ruth-E. Mohrmann, Alltagswelt im Land Braunschweig: Städtische und ländliche Wohnkultur vom I6. bis zum frühen 20. Jahrhundert (Münster, 1990); Daniel Roche, The People of Paris: An Essay in Popular Culture in the 18th Century trans. by Marie Evans (Berkeley, CA, 1987); Roman Sandgruber, Die Anfänge der Konsumgesellschaft: Konsumverbrauch, Lebensstandard und Alltagskultur in Österreich im 18. und r9. Jahrhundert (Vienna, 1982); Sylvia Schraut, Sozialer Wandel im Industrialisierungsprozess: Esslingen 1800-1870 (Esslingen, 1989); Carole Shammas, The Pre-industrial Consumer in England and America (Oxford, 1990); and Lorna Weatherill, Consumer Behaviour and Material Culture in Britain, $1660-1760$ (New York, 1988).

2. Hans Medick's work, i.e. Weben und Überleben in Laichingen 1650-1900: Lokalgeschichte als Allgemeine Geschichte (Göttingen, 1997), is a clear exception, and serves, in fact, as one of the models for my own work. 
poorer households as they struggled to avoid the abject indigence of the truly destitute.

Among scholars who study inventories, the work of Pierre Bourdieu has provided not only the inspiration but also a conceptual framework for using these sources. In Distinction, Bourdieu revealed all of the available strategies that individuals and social groups rely on as they move through their social space. According to Bourdieu, movement through this social space has never been - and never will be - random; numerous forces act on individuals, pushing and pulling them through society, as they consciously or unconsciously accept some of those forces while consciously or unconsciously resisting others. ${ }^{3}$ Since an intrinsic and reciprocal relationship exists between individuals and the social space that surrounds them, all components of that space whether material (i.e. material culture) or immaterial (i.e. practices) simultaneously reflect and shape the "habitus", or behaviors and strategies, on which individuals depend. Therefore, argues Bourdieu, all elements of material culture should be considered as forms of economic, social, and cultural capital. These persuasive conclusions further buttress the need for a more nuanced study of early-modern probate inventories that adequately reflects the social, cultural, and economic aspects of material culture.

These relatively new source materials can, however, be problematic. ${ }^{4}$ While the inventories from Württemberg were supposed to list the entirety of a family's property, including any outstanding loans or debts, items could have been hidden or liquidated before the notary visited. Worse yet, the death inventories oftentimes captured household economies at strikingly different stages, depending on the circumstances of the deceased. If death came too early for the husband or wife, then the probate inventory came from a household economy that probably had not yet reached its full potential. Inventories from particularly old individuals could reflect household economies that had clearly passed their prime. Lastly, the inventories from Swabia rarely listed the rooms, or location, in which the items were found. Still, these documents offer an unparalleled glimpse into the material culture of ordinary families and households. This has provided scholars with the incomparable opportunity to study the material culture of many households

3. Pierre Bourdieu, Distinction, transl. by Richard Nice (Cambridge, MA, 1984), p. Iro.

4. For further details on the problems inherent to studying inventories, see, among others: Peter King, "Pauper Inventories and the Material Lives of the Poor in the Eighteenth and Early Nineteenth Centuries", in T. Hitchcock, P. King, and P. Sharpe (eds), Chronicling Poverty: The Voices and Strategies of the English Poor, 1640-1840 (New York, 1997), Pp. 161-166; Hildegard Mannheims, Wie wird ein Inventar erstellt? Rechtskommentare als Quelle der volkskundlichen Forschung (Münster, 1991), pp. 12I-I34; Medick, Weben und Überleben, pp. 398ff.; Ruth-E. Mohrmann, "Archivalische Quellen zur Sachkultur”, in Günter Wiegelmann (ed.), Geschichte der Alltagskultur, Heft 2r (Münster, 1980), pp. 69-86; and Bernard Vogler (ed.), Les actes notariés: Source de l'bistoire sociale XVie-XIXe siècles (Strasbourg, 1979). 
from a variety of social groups in this region..$^{5}$ The inventories from the "orderly-built, friendly city" of Göppingen, which date back to 1738 , have yet to be examined. ${ }^{6}$

Göppingen, which still lies on the major thoroughfare between the large, regional centers of Stuttgart and Ulm, was well situated in the "urban network" of southwest Germany. ${ }^{7}$ As a consequence of this ideal setting, handicrafts, but especially those involved in the manufacture of woolen worsteds (Zeuge), and in the production of foodstuffs, dominated this economy. These trades, and others, experienced the vicissitudes common to the protoindustrial economies of the eighteenth and early nineteenth centuries. The annual commercial registers, which listed the yearly, variable tax paid by all artisans according to their profitability, recorded these ups and downs in Göppingen's economy (see Figure I below). Numerous events, both from within and without, affected the economic activity of the small-scale producers in this town. A cataclysmic fire, for example, burnt nearly the entire city to the ground in 1782 . There was also a burgeoning population in the late eighteenth and early nineteenth centuries that expanded from 2,912 inhabitants in 1760 to 5,490 in $1837 .^{8}$ This undoubtedly put yet further strain on an economy that, for the most part, remained in the doldrums. However, beginning with the I820s, two quiet decades brought not only new opportunities for economic growth but also new pressures before economic and political tumult once again hit in the 1840 s. $^{9}$ Thus, Göppingen is an excellent case study for investigating the strategies used by poor households as they wrestled with these economic tribulations.

A sample set of 348 probate inventories was studied for the years from 1738 to 1827 . In order to provide a frame of reference, the total wealth, or net worth, of each single inventory was calculated through the following formula:

5. Among many studies, see Benscheidt, Kleinbürgerlicher Besitz; Peter Borscheid, Textilarbeiterschaft in der Industrialisierung (Stuttgart, 1978); Hauser, Dinge des Alltags; Heilwig Schomerus, Die Arbeiter der Maschinenfabrik Esslingen (Stuttgart, 1977); and Schraut, Sozialer Wandel im Industrialisierungsprozeß.

6. Karl Chr. Fr. Pistorius, Taschenbuch auf Reisen durch Wïrtemberg; mit einem Anhang über die besuchteren Bäder Würtembergs, einem Ortsregister und zwei lithographirten Abbildungen, auch auf Verlangen mit einer Charte (Stuttgart [etc.], I827), p. III. Unless otherwise noted, all translations are mine.

7. For more details, see Karl Kirschmer, Die Geschichte der Stadt Göppingen, 2 vols (Göppingen, 1953); Emil Hofmann, Die Industrialisierung des Oberamtsbezirkes Göppingens (Göppingen, 1910); Walter Troeltsch, “Die Göppinger Zeugmacherei im 18. Jahrhundert und das sog. Vayhingerbuch", in G. Schmoller (ed.), Jahrbuch fir Gesetzgebung, Verwaltung und Volkswirtschaft im Deutschen Reich (Leipzig, 1896), pp. 165-187; and Alexander Dreher, Göppingens Gewerbe im 19. Jabrhundert (Göppingen, 1971).

8. Cf. Stadtarchiv Göppingen (hereafter StAG), B.II.6.a, Seelentabellen und Bürgerlisten, I760; and Hofmann, Die Industrialisierung, p. 168.

9. See Dreher, Goppingens Gewerbe, pp. 9-18; and Hofmann, Die Industrialisierung, pp. 3-10. 


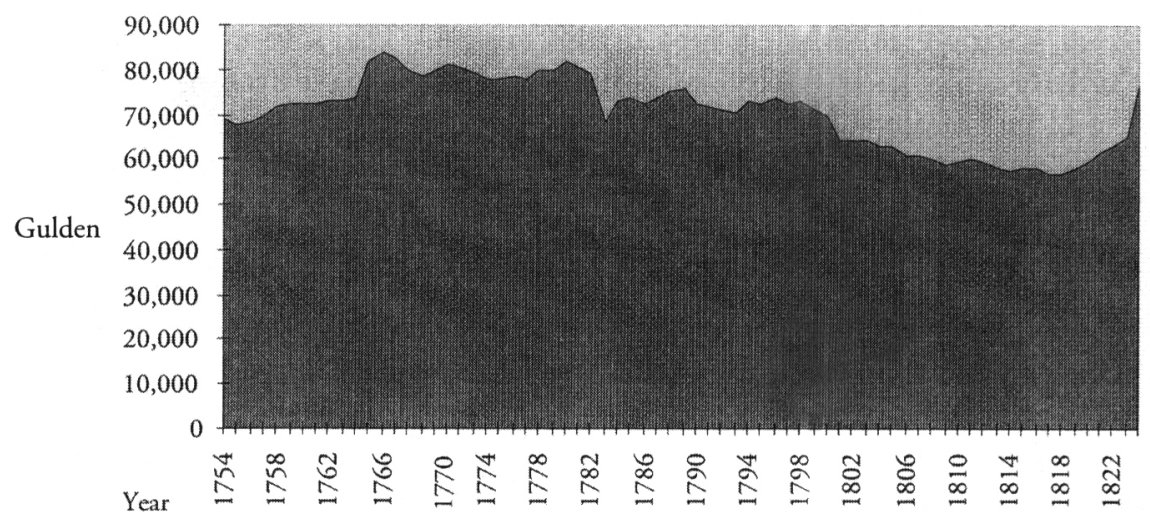

Figure I. Total annual commercial tax of all trades in Göppingen (1754-I824)

Sources: StAG, Commerzienregister

Net worth or total wealth $=$ aggregate property ${ }^{\text {io }}+$ loans outstanding (Activa) - debts owed (Passiva).

With net worth calculated, the households were then sorted into three thirty-year intervals (i.e. $1738-1767,1768-1797$, and 1798-1827). And, finally, using a normal distribution, the households were partitioned into the following three wealth strata:

Table I. Social stratification of cases by net worth in Gulden (1738-1827)

\begin{tabular}{l|c|c|c}
\hline Decade & Lower stratum (25\%) & Middle stratum (50\%) & Upper stratum (25\%) \\
\hline 1738-1767 & $21.35 \leq 360.83$ & $361.04 \leq 1,385.88$ & $1,392.48 \leq 12,205.63$ \\
Average & 229.18 & 675.14 & $3,073.69$ \\
Number & 29 & 58 & 30 \\
\hline $1768-1797$ & $21.77 \leq 483.70$ & $486.14 \leq 2,330.87$ & $2,332.37 \leq 8,996.10$ \\
Average & 257.82 & $1,155.14$ & $4,291.60$ \\
Number & 31 & 61 & 31 \\
\hline 1798-1827 & $-54.03 \leq 571.65$ & $572.70 \leq 3,253.18$ & $3,588.18 \leq 18,482.75$ \\
Average & 264.55 & $1,603.08$ & $6,027.95$ \\
Number & 27 & 54 & 27 \\
\hline
\end{tabular}

Sources: StAG, Inventuren und Teilungen

10. The corresponding categories from the probate inventories were as follows: Aggregate property $=$ real estate + cash + precious items + books + male clothing + female clothing + bedding + linens + brass utensils + tin utensils + copper utensils + iron utensils + tinplate utensils + wooden utensils + furniture + barrel and binding materials + common household goods and tools + harness, tack, and building materials + craftsman tools, supplies, and wares + livestock + produce + foodstores + supplies + wine and other drinks. 


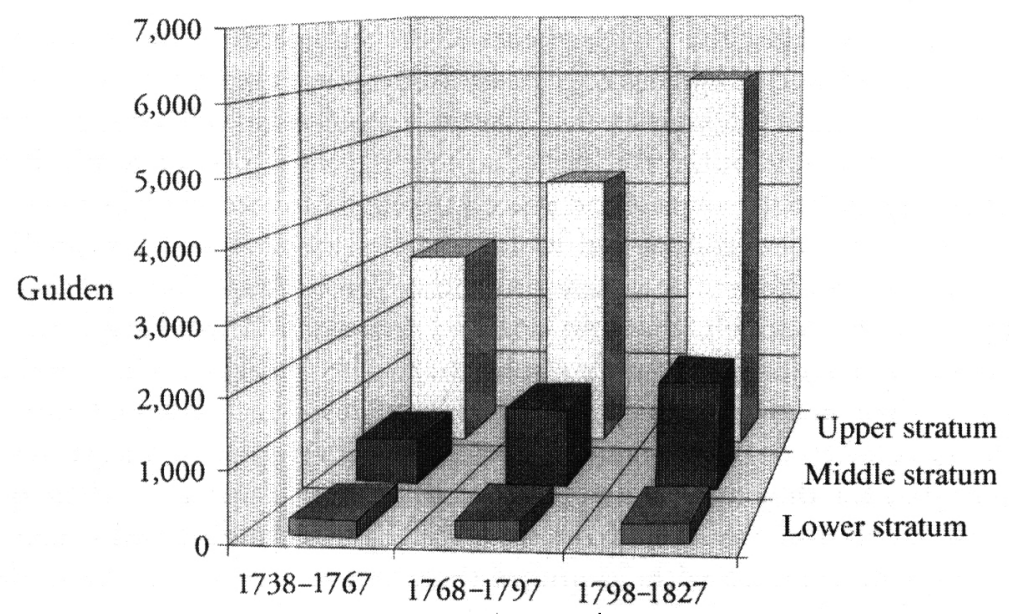

Figure 2. Average net worth in Gulden by wealth stratum (1738-1827)

Sources: StAG, Commerzienregister

With the 348 cases separated into their respective social strata, it was simple to chart the average net worth for each social stratum, and the results were startling (see Figure 2). The net worth of the families in the lower stratum clearly stagnated throughout the period, holding steady somewhere between 200 and 300 Gulden. ${ }^{I I}$ While they were not the poorest of the poor in their town, the lower-stratum families were clearly struggling to make ends meet. The average total wealth of the other two strata showed, on the other hand, steady growth over the ninety years studied, with the upper stratum clearly outpacing the middle stratum. Therefore, the basic trend in wealth was one of growing disparity among the strata, which had, as will be shown below, serious consequences for the poorer artisanal households in Göppingen.

Evidence from the inventories suggests that even as these disparities grew, households in all three strata employed a striking resourcefulness as they tried to piece together a variety of sources of income. Ernst Jacob Vayhinger, a Zeugmacher (woolen worsted weaver), who lived from 1729 to 1791 and kept a chronicle during the years from 1756 to 1784 , epitomized this. This eighteenth-century weaver, who would become part of the upper stratum, started off his adult life in an inauspicious manner when at the age of twenty-five or twenty-six he married his spouse, Anna Barbara, née Schaupp, in 1755 . According to their wedding inventory, the parents of the newlyweds showered them with generous gifts worth 289 fl. 13x., which gave them when combined with their own property (i.e. 174fl. 59x.) a net worth

II. During this entire period, the currency in Württemberg was: I Gulden $(\mathcal{H})=.60 \operatorname{Kreuzer}(\mathbf{x}$.). 
of $464 \mathrm{fl} .12 \mathrm{x} .{ }^{12}$ During the "golden years of the eighteenth century" inherited wealth (Startkapital) could, as argued by Hans Medick, play a decisive role in how a family fared later in life, because it often saved young families from serious capital outlays. ${ }^{13}$ Indeed, their parents' gifts certainly helped the Vayhingers get off to a good start in their wool-weaving business, for Ernst Jacob recorded annual profits for the first ten years of his own business. $^{14}$ Those times were not easy ones; the Seven Years' War (1756-1763) disrupted trade so much, that "no one had any worsted wool" and the craft went into dire straits. ${ }^{15}$ From this solid start, the Vayhingers methodically increased their net worth to 2,95ofl. 32X. in 1792 when Ernst Jacob died.

The generosity of Vayhinger's parents did not stop with the aforementioned gifts, for they agreed in 1758 to sell the "upper part" of their house to Ernst Jacob and Anna Barbara for 215fl. Even though Ernst Jacob and Anna Barbara came up with "no more than 75 Gulden" of the Ioofl. down payment, the elder Vayhingers apparently did not mind, for the transaction was completed without further mention. ${ }^{16}$ And, following the death of his mother in 1773 - his father had died in 1763 - Ernst Jacob acquired his mother's portion of the building, which meant that he now owned "threefourths" of it. ${ }^{17} \mathrm{He}$ would eventually acquire the entire building when, in 1775, he purchased the "bottom part" of it for $200 \mathrm{ol}$. from one of the town's curates, named Stimmel. ${ }^{18}$ This "three-story building" with a garden "behind the house [...] and [stretching to] the city wall", was worth 2,000fl. in $1789 .^{19}$ It housed three of the Vayhingers' four economic activities: weaving woolen worsteds, raising pigeons and canaries, and renting out space in their home. The fourth economic activity (i.e. farming) took place primarily on the community plots that the family apparently leased from the town. ${ }^{20}$ However, they may have also used "the half of [a] $1 / 2$ Vrtl. [i.e. a Viertel of cultivable land] under the paper mill", which was worth $34 f$., or perhaps the garden behind the house, for small horticulture. ${ }^{2 \pi}$ All told, then, the

12. See Kirchenregisteramt Göppingen (hereafter KrtG), Familienregister, 1558-1800, Sch-Z, 608636, p. 432; and StAG, B.II.2g, Zubringens Inventuren vom 23. Jan. I750 biß 20. Febr. 1756, p. $56 \mathrm{ib}$.

13. Medick, Weben und Überleben, pp. 212-228.

14. StAG, B.I.I.a, Hauschronik des Zeugmachers Ernst Jakob Vayhinger, pp. 8-19.

15. Ibid., p. 9. See also Troeltsch, "Die Göppinger Zeugmacherei", p. 185.

16. StAG, B.I.I.a, Hauschronik des Zeugmachers Ernst Jakob Vayhinger, p. IO.

17. StAG, Wirtschaftliche Lage in Stadt u. Amt 1622-1819; Schulden 1824/25, "1774 Tabellen wirtsch. Art".

18. StAG, B.I.I.a, Hauschronik des Zeugmachers Ernst Jakob Vayhinger, pp. 35 and 50.

19. StAG, B.II.2.g, Inventuren und Teilungen, 23.2-209.5 (1789).

20. Unfortunately, the Vayhingers' inventories do not make clear how households gained access to these community plots. This was not unusual, for the probate inventories rarely listed the terms of use. Occasionally, the inventories did list the value of such community plots under the household's immovable property. This was, however, not the case with the Vayhingers.

21. StAG, B.II.2.g, Inventuren und Teilungen, 23.2-209.5 (1789). The land measurements during this period were as follow: I Viertel $=0.25$ Morgen; and I Morgen $=0.78$ acre $=0.32$ hectare. 
Vayhingers owned real estate that totaled 2,034fl. in 1789 . At the same time, the net worth of the Vayhingers' estate (including the additional value of loans extended but not collected, and subtracting the value of debts still owed) was $2,727 \mathrm{fl}$. 37x. Therefore, as a percentage of net worth, real estate equaled 74.57 per cent. Between the time of Anna Barbara's death (1789) and Ernst Jacob's in 1792, the value of the Vayhinger real estate did not change, but their total wealth did, increasing to 2,950f. 31.5x. ${ }^{22}$ Thus, in 1792, the house on Pfarrstraße and the plot of land under the paper mill constituted 68.94 per cent of the Vayhingers' total wealth. In general, then, real estate consistently made up about 70 per cent of their total wealth; in effect, immovable property was the cornerstone of the Vayhingers' wealth. This behavior resembled that of their fellow middling-to-wealthy artisans in Göppingen and other artisans elsewhere in Swabia. ${ }^{23}$

The significance of real estate, including both buildings and arable lands, for the Handwerker in general and for the Vayhingers in particular, cannot be understated. After all, the land and the building(s) which usually stood on it housed not only the Handwerker family, but also the very workshop which kept them solvent. In fact, the two spaces were firmly intertwined. In the case of the Vayhingers, they may have devoted three rooms in their house to Zeugmacherei. They had had, according to Ernst Jacob's chronicle, "three ovens" in their home prior to the city-wide fire on 26 August 1782; hence he could have easily heated three different rooms for weaving. ${ }^{24} \mathrm{He}$ and his family certainly had more than one loom operating at a time. Their first loom came as a wedding gift from Ernst Jacob's parents. In mid-to-late 1763, Ernst Jacob used the profits of the preceding year to improve this loom and to have a yarn mill built. Then, in his chronicle entry from 1767 , Ernst Jacob mentioned that "on Martini [II November]" he gave his "Gesellen Feier-Abend", which clearly indicates that he worked with journeymen. And, since both of Vayhinger's sons eventually became Zeugmacher, they probably assisted him in weaving, too. Moreover, the Vayhinger household also engaged in putting out, for after the city-wide fire of 1782 consumed their home, the wife of one of "his [out-]workers" in Lorch, a town $16 \mathrm{~km}$ to the north, offered Vayhinger "their entire house" as temporary housing. ${ }^{25}$

Thus, the Vayhingers owned only 0.04875 acres or 0.02 hectares. David Sabean, in Property, Production, and Family in Neckarhausen (Cambridge, 1990), argues that anything less than 1.5 hectares was "clearly less than adequate land to live from agriculture alone" (p. 39). Obviously then, this tiny plot of land did not mean annual self-subsistence for the Vayhingers.

22. Cf. StAG, B.II.2.g, Inventuren und Teilungen, 23.2-209.5 (1789), and 24.2-405.5 (1792).

23. See Medick, Weben und Überleben, pp. $183-228$, where he argues that real estate often made up the largest chunk of wealth among his linen weavers. When, for instance, the linen weaver Michael Schwenk died in 1748 , landed properties, according to Medick's calculations, constituted seventy per cent of his estate's total worth (p. 198).

24. StAG, B.I.I.a, Hauschronik des Zeugmachers Ernst Jakob Vayhinger, p. 53.

25. Ibid., pp. 16-23. 
The probate inventories from Anna Barbara and Ernst Jacob shed even more light on the way in which the Vayhingers conducted their household economy. In 1789, when Anna Barbara died, the notary wrote that the craft tools in the household "were estimated in general, together with all items, at $50 \mathrm{fl}^{\mathrm{D}}{ }^{26}$ Although the notary failed to take an item-by-item list of those tools, he was more precise with his list of the "Handthierungs-Waaren" (i.e. supplies and wares) found in the Vayhinger household, describing twelve items that were worth a sum total of $632 \mathrm{fl}$. 30x. With a good number of supplies and wares, the Vayhingers plied their trade vigorously. In fact, craft tools, wares, and supplies constituted in 1789 just over 25 per cent of the Vayhingers' net worth. Because none of those wares and supplies were found three years later in Ernst Jacob's death inventory, this statistic dropped dramatically to 0.44 per cent in 1792 ; according to his probate inventory, Ernst Jacob had liquidated most of his Handthierungs-Waaren in August I79I by selling them, on credit, to his sons. ${ }^{27}$ Like his father before him, Ernst Jacob provided his sons with some Startkapital.

Aside from the large number of supplies and wares, Anna Barbara's inventory of 1789 also listed numerous and expensive loans worth $1,464 \mathrm{fl}$. $57 \mathrm{x}$. that the Vayhingers had extended. In terms of total wealth, this category of loans extended, or Activa, comprised over fifty per cent of the Vayhingers' net worth. In real terms, all of these loans came from merchandise that the Vayhingers gave on credit to "various friends" and "merchants" located well outside the walls of Göppingen. ${ }^{28}$ These far-reaching credit lines for finished woolen worsteds suggest that Vayhinger followed the common behavior of cutting out the middleman by participating in the trade and marketing of his merchandise. The extension of generous credit lines was not only an innovative behavior, but it was also, according to Medick, essential to "the maintenance and expansion of [...] a Weber-Marchand's (weavermerchant's) activities in a constrictive economy. ${ }^{29}$ With multiple looms, outworkers, stockpiled goods, and their own merchandizing, the Vayhingers therefore practiced their trade in not only an assiduous, but also a venturesome manner.

The Vayhingers were, as the chronicle constantly implies, active gardeners. Ernst Jacob noted in one of his entries from I77I that, after gathering produce "from [his] community plots", he "immediately sold" it for 27 Gulden. ${ }^{30}$ Two years later (1773), Vayhinger wrote that " $[t]$ his year I had, thank goodness, a robust year". He then proceeded to list the sources of his revenue:

26. StAG, B.II.2.g, Inventuren und Teilungen, 23.2-209.5 (1789).

27. StAG, B.II.2.g, Inventuren und Teilungen, 24.2-405.5 (1792).

28. StAG, B.II.2.g, Inventuren und Teilungen, 23.2-209.5 (1789).

29. Medick, Weben und Überleben, p. 239.

30. StAG, B.I.r.a, Hauschronik des Zeugmachers Ernst Jakob Vayhinger, p. 31. 
From 3 [of his] community plots [he] cut 40 bushels barley, from the fourth plot 30 bushels potatoes [and] $2 \frac{1}{2}$ bushels beans. From [the sale of] four of my male canary birds came $48 \mathrm{fl}$ [Gulden]. Because this year, they were quite rare. [And] because everything came off [well] due to the rise in prices; [he] won with the help of God $210 \mathrm{fl}[\ldots]$.

Only after explaining that some of this profit was consumed by an outstanding debt owed for taking over the entire house from his recently deceased mother, did Vayhinger turn to the primary trade of his household: weaving woolen worsted. Here, he briefly mentioned that seventeen Centner of wool "from the town shepherds" of three surrounding towns had been worked." Apparently then, throughout their adult, married lives, the Vayhingers made good use of their share of the common lands, even hiring farmhands to assist in their endeavors. ${ }^{32}$

The Vayhingers also engaged in a third economic pursuit: animal husbandry. In 1755, as the notary took down the marriage inventory of Ernst Jacob and Anna Barbara, he recorded "two bird cages" and "twelve pairs of pigeons" worth a total of $2 \mathrm{fl}$. $15 \mathrm{x}$. Carefully cultivating these original twentyfour pigeons, Ernst Jacob more than doubled their number by 1782, for that was when "not more than five of [his] fifty pigeons escaped [the city fire] with their lives" ${ }^{33}$ Expanding his efforts at animal husbandry, Ernst Jacob even began to raise canaries during the difficult years between 1764 and I766. These birds were a significant source of the household's annual income in late 1772, when they comprised nearly one-quarter (i.e. 22.9 per cent) of the annual profit for that year (i.e. 2rofl.). Perhaps more significantly, the solid income came at a particularly good time for the Vayhingers. During the years from 1770 to 1772 , they, along with the rest of Göppingen, lived through famine and its concomitant, a severe rise in prices. Sometime during this famine, their canaries led Ernst Jacob and one of his sons on a journey to Schwäbisch Gmünd, "because the bird merchants were there" ${ }^{34}$ Since the Vayhingers could not control the outside forces that led to the downturn in weaving, they aggressively tried to compensate for that lost, or slackened, enterprise by increasing their other undertakings.

Besides animal husbandry, Ernst Jacob and Anna Barbara profited from a fourth economic activity: renting out the bottom floor of their three-story house. They became landlords as soon as they took over the lower part of the house in 1775. Although leasing space in one's house was quite common among artisans and others in many large and medium cities throughout

\footnotetext{
31. Ibid., p. 33 .

32. Ibid., p. 14 .

33. Cf. StAG, B.II.2.g, Zubringens Inventuren vom 23 Jan. 1750 biß 20 Febr. 1756, p. 56rb; and StAG, B.I.I.a, Hauschronik des Zeugmachers Ernst Jakob Vayhinger, p. 54.

34. StAG, B.I.1.a, Hauschronik des Zeugmachers Ernst Jakob Vayhinger, p. 47.
} 
early modern Europe, ${ }^{35}$ Vayhinger's chronicle implies that this type of activity was relatively new to Göppingen. The Vayhingers had a succession of three different tenants between 1775 and 1782 , but when the city-wide fire consumed the house in the latter year, the Vayhingers' tenants also lost their quarters. Although Ernst Jacob discussed how difficult it was to rebuild the "lower floor", he made no further mention of any other tenants in the last two years of his chronicle. ${ }^{36}$ Nor could a statement of how much money he made from this rental property be found. While it would be useful to know what percentage of the Vayhingers' income derived from their tenants, in this case it does not really matter. What matters is that they demonstrated their flexibility and an entrepreneurial attitude by employing yet another strategy available for their use.

Here was a family that expanded and diversified its household economy in a number of ways, evidently in an attempt, not only to remain competitive in trying economic times, but also to aggrandize its wealth. And the Vayhingers' efforts yielded high dividends. Between 1755 and 1789 , their total wealth increased sixfold, moving from about $464 \mathrm{fl}$. in 1755 to just over 2,720f. in 1789 . This household net worth placed the Vayhingers, according to the wealth stratification for the period from 1768 to 1797 , firmly in the upper stratum in Göppingen. In the three years between Anna Barbara's death (1789) and Ernst Jacob's death (1792), the total wealth of the Vayhinger household increased by just over 200 Gulden from about 2,720 fl. to 2,950f. This increase apparently came from two significant moves by Ernst Jacob. First, he liquidated most of the wares and supplies in his workshop just before his death, and second, he drastically reduced the loans outstanding and debts owed. With decreases in both loans and debts, it appears that Vayhinger tried to clear his books so that the slate would be clean for his sons after his death. He had, in fact, paid down all of the outstanding debts for cash that had appeared on his wife's probate inventory in $\mathbf{1 7 8 9}$. Only one of the three Passiva in 1792 stemmed from cash (78fl. $45 \mathrm{x}$.) that was owed. The other two came from services rendered by the "barber Laichinger" (3fl. Iox.) and from back taxes in the amount of rofl. $5 x \cdot{ }^{37}$ By reducing the debt burdens that would be passed on to his successors, he provided his sons with a rather large patrimony (Startkapital) that furnished them with a solid foundation for their own industrious households.

The Vayhingers' high yields attest to the successful combination of a number of economic strategies for dealing with an unpredictable world. However, not all Handwerker households had the same resources. Three case studies from the lower stratum make this crystal clear. The Greiners,

35. See Wolfgang von Hippel, Ute Mocker, and Sylvia Schraut, "Wohnen im Zeitalter der Industrialisierung. Esslingen am Neckar 1800-1914", Esslinger Studien, 26 (1987), pp. 137f.; Roche, The People of Paris, pp. 103-110; and Schraut, Sozialer Wandel, pp. 252-258.

36. StAG, B.I.I.a, Hauschronik des Zeugmachers Ernst Jakob Vayhinger, Pp. 42-63.

37. Cf. StAG, B.II.2.g, Inventuren und Teilungen, 23.2-209.5 (1789), and 24.2-405.5 (1792). 
for instance, were shoemakers that lived and worked in "half of a two-story house" valued at 350fl. in 1779. They owned no other real estate. This portion of a building was a mere fragment of the Vayhingers' immovable property, worth 2,034 $\mathrm{f}$. in $1789 .^{38}$ The Greiners - Georg Adam Greiner and Maria Barbara, the widow of Andreas Schieck, a stone-cutter in the neighboring town of Winterbach - had married in 1768; unfortunately, their marriage inventory could not be located, so it is impossible to determine their Startkapital. However, since Maria Barbara came into the marriage from outside Göppingen and from a different trade, it would seem likely that Georg Adam did not inherit an already established household economy, as was frequently the case when one married the widow of an artisan. ${ }^{39}$ Apparently, the newlyweds lived in a residence owned by others until $\mathbf{1 7 7 2}$, when, according to the annual tax register, they first began to pay property taxes of their own. ${ }^{40}$

The tax rolls also indicate that the Greiners' shoemaking business was not nearly as dynamic as the Vayhingers' weaving business. Whereas the Greiners paid $75 \mathrm{fl}$. for commercial taxes in 1779 , the Vayhingers paid $300 \mathrm{fl}$. in the same year. In fact, throughout the I780s, the taxes assessed on the Vayhingers were no less than 25ofl., while those assessed on the Greiners were no more than I5off..$^{4}$ To be sure, though, Maria Barbara's probate inventory, which lists a "four-poster bedframe [and an] old trunk in the journeyman's room", implies that the Greiners may have had someone outside the immediate family circle working with them. ${ }^{42}$ The possible existence of a journeyman or an apprentice would have been offset by the rather heavy debt burden that they carried in 1779. As listed in the inventory, the Greiners had extended loans worth $45 \mathrm{fl}$., but had incurred outstanding debts totaling 303fl. 35x.; while about one-quarter of that debt came from back taxes (i.e. I 4 fl. $40 x$. , or 4.83 per cent) and from back rent ( 60 f., or 19.76 per cent), the remainder of the debt came from the two noteworthy categories of borrowed cash and supplies taken on credit. ${ }^{43}$.The Greiners had borrowed 12Ifl. 66.5x. in cash from various wealthy creditors, like the Gerichtsverwandt (justice of the court) Erhardt, and institutions, like the Armenkastenpfleg (the poor relief fund). In addition, they had taken on credit leather valued at 4 ofl. from the wealthy tanner Widmann and another 6ofl.-worth of

38. StAG, B.Il.2.g, Inventuren und Teilungen, 19.2-49.5 (I779).

39. KrtG, Familienregister, $1558-1800, A-G, 608-634$, p. 861, and Göppingen Familien-Register, Bd. 2, 608-2, p. 429. Winterbach is located about $25 \mathrm{~km}$ northwest of Göppingen.

40. Cf. StAG, B.II.5.d, Steuervermögensregister, 1764-1773 Haußgenoßen, Strb. [blank]; and Steuervermögensregister, 1764-1774 Drittes Viertel. Löw, Strb. 129.

4I. See StAG, B.II.5.d, Steuervermögensregister, I779-I782 Löw No. 78; Steuervermögensregister, 1783-1787 Haußgenoßen; Steuervermögensregister, 1783-1791 Ochs No. 89 1/8; Steuervermögensregister, 1779-1782 Löw No. 96; and Steuervermögensregister, 1783-1991 Löw No. 12.

42. StAG, B.II.2.g, Inventuren und Teilungen, 19.2-49.5 (1779).

43. Ibid. 
leather from the tanner Schaufler. ${ }^{44}$ This household of impecunious cobblers thus lived close to the edge, perhaps even von der Hand in den Mund, for if the Greiners defaulted on their numerous debts, then their real estate, the only significant asset of their net worth, would have been jeopardized. What happened to the Greiner household following the death of Maria Barbara is not entirely clear, for Georg Adam's probate inventory could not be located. Surrounding sources, however, suggest that Georg Adam remarried less than six months after Maria Barbara's death. He and his new wife, Anna Maria, née Beisser, had six children, four of whom apparently survived to adulthood, and their household economy continued to plod along, paying a steady $25 \mathrm{fl}$. in commercial taxes throughout the 1790 , until Georg Adam died in 1806.45

Although the Endriß household engaged in a different trade, their situation did not differ much from that of the Greiners. In 1798, Johann Georg Endriß, a twenty-three-year-old butcher, married Margretha Schrag, the twenty-six-year-old widow of Johann Georg Bacher, also a butcher. ${ }^{46}$ Since their marriage inventory was not found, their early material culture and Startkapital remain unknown. According to the annual tax rolls from 1801 to $18 \mathrm{rr}$, though, the Endrißs paid substantial property taxes of $462 \mathrm{fl}$. in $180 \mathrm{O}$, 3919. in 1802, and 453 fl. in 1806; their commercial taxes during the same period paled in comparison (i.e. $25 \mathrm{fl}$. for 1801,1802 , and 1806 ) ${ }^{47}$ While they owned considerable and wide-ranging farmland, which they evidently turned to agriculture and pasturage, Johann Georg and Margretha had a dismal trade in butchering. In fact, the Endrißs would request and receive a grant of soofl. from the Armenkastenpfleg in 1803, using their extensive real estate as collateral. ${ }^{48}$ As far as can be gathered, the Endrißs acquired this loan in order to purchase more land. Perhaps they had hoped to expand their farming endeavors. If so, they were unsuccessful, for when Johann Georg's death inventory appeared twenty-four years later in 1827 , this debt was still pending, along with nineteen other outstanding debts for a total of $1,546 \mathrm{fl}$. 23x. The largest portion of this debt came from borrowed cash, which totaled I,373 Hl. 39x.; the second largest portion was for services rendered on credit, tallying $70 \mathrm{fl}$. 40x.; another $62 \mathrm{f}$., the third largest, stemmed from administrative costs; the fourth chunk came from raw materials and goods in the amount of 2ofl. 8x. that had been purchased on credit; and lastly, the household owed I9f. 39x. in back taxes. ${ }^{49}$ Like the Greiners, the Endrißs had turned to the town's poor relief institution for an injection

44. Ibid.

45. KrtG, Göppingen Familien-Register, Bd. 2, 608-2, p. 429.

46. Ibid., p. I40.

47. StAG, B.Il.5.d., Steuervermögensregister, 1801-1811 Ochs, fo. 395.

48. Cf. StAG, B.II.2.b, Gerichts Protocolle, p. 207 (5 Sept. 1803); and StAG, B.II.2.g, Inventuren und Teilungen, 239--12a (1827).

49. StAG, B.II.2.g., Inventuren und Teilungen, 239-12a (1827). 
of hard capital, but unlike the Greiners, the Endrißs did not turn to the wealthy for additional loans. Instead, these poor butchers had turned to their apparently wealthy brother-in-law, Christoph Endriß, a tanner who loaned them $423 \mathrm{fl}$. between $18 \mathrm{r} 3$ and $1826 .^{50}$ Ultimately, the Endrißs' total debt owed was greater than their aggregate property (i.e. $1,522 \mathrm{fl}$. 35x.), which meant that, like the Greiners, they had a precarious existence, always on the brink of disaster. In 1823, four years before Johann Georg's death, the tax roll listed the household industry as without journeymen or apprentices and as procuring only "humble earnings" ${ }^{\text {.I }}$ Evidently, the heavy debt load, which the Endrißs created by borrowing significant amounts of cash since at least 1803 , sapped the vitality of their household economy, and the only way to survive was to borrow heavily from their generous brother-inlaw.

The third case study, the Maiers, established their household economy in $\mathbf{1} 783$ when Johann David Maier wedded Sibilla Magdalena, née Vöster. According to their marriage inventory, they began with $460 \mathrm{ofl}$. rox. in Startkapital. About two-thirds of it came from their parents, who presented them with cash wedding gifts: Johann David's father gave them 2oofl., while Sibilla Magdalena's mother gave roofl..$^{52}$ At their nuptials, Johann David, a turner originally from the town of Adelmannsfelden, was four days short of his twenty-fourth birthday, while Sibilla Magdalena, the daughter of a cowherd in Göppingen, had just turned twenty-five. ${ }^{53}$ Whether they lived at first with Sibilla Magdalena's parents or elsewhere in Göppingen is unclear, but the tax rolls do clearly indicate that they did not pay any property taxes until I791, when they began to pay 35f. in taxes on their "half of a two-story Häuslen [i.e. a small house]" ${ }^{54}$ The value of this building could not be established, because neither the tax documents nor the probate inventory for Johann David listed its value. In fact, according to Johann David's probate inventory, the Maiers had at some time before 1827 lost all proprietary rights to this small house..$^{5}$ The tax registers also suggest that the Maiers had little success at their lathe-operating business. They were never assessed for more than $25 \mathrm{fl}$. in commercial taxes during the period from I 783 to 180 I; they paid no commercial taxes whatsoever in 1787, 1791, and 1792; and in 1823, their household economy was listed as "very poor [because father and son] pursued the trade quite feebly", with the son, Johann Georg,

\section{5o. Ibid.}

5I. StAG, B.II.7.c, Gewerbe Steuer I823, p. 4b.

52. StAG, B.II.2.g, Zubringens Inventuren vom 13. Jun. 1779. bis 31. Merz. 1784., p. 427.

53. KrtG, Göppingen Familien-Register, Bd. 4, 608-4, p. 147. Adelmannsfelden is located about sixty $\mathrm{km}$ northeast of Göppingen.

54. See StAG, B.II.s.d, Steuervermögensregister, $1783-1787$ Haußgenoßen; Steuervermögensregister, 1787-1790 Haußgenoßen; Steuervermögensregister, 1791-1801 Wolf No. 288; Steuer und Guther Buch. Renoviert 1790. IV. Viertel Wolf, p. 288; and Gewerbe Steuer 1823, p. 43b.

55. StAG, B.Il.2.g, Inventuren und Teilungen, 239-IIa (I827). 
apparently serving as the single journeyman employed by the household business. ${ }^{56}$ To be sure, at sixty-four years old, Johann David's household industry had most likely passed its prime, but still the household industry had not come even close to the solid rewards that were reaped by the Vayhingers' business. Indeed, the net worth of the Maier household in 1827, when Johann David died at the age of sixty-eight, was the paltry sum of 8fl. 9x. His Schulden (debts) played a significant role in reducing the estate to such a negligible level, for they totaled I49fl. 56x. Maier owed " $7 \mathrm{Ifl}$. [in] outstanding HausZins (rent)" to Michael Endriß (a tanner in Göppingen), "7ofl. 56x." in borrowed cash, and "8fl." from wares that he had purchased on credit. ${ }^{57}$ No evidence could be found of Maier making provision for providing his son with a solid patrimony as Vayhinger had done with his two sons.

With fewer resources, the lower-stratum artisans had fewer economic strategies available to them. Households, such as the Greiners, Endrißs, and Maiers, did not have the wherewithal to diversify their economic pursuits, and as we have seen, this flexibility was crucial for the survival and success of the Vayhinger household. This also seems to have been the case in nearby Laichingen, where Medick's linen-weavers weathered the economic fluctuations of the eighteenth and nineteenth centuries by changing their economic behaviors accordingly. When new opportunities in the linen industry presented themselves during the golden years of the second half of the eighteenth century, many linen-weavers expanded their small-scale production by investing more heavily in that sector than in land, even though "landed resources remained important". But when stagnation hit at the end of the eighteenth century, the linen-weavers who survived best were the ones, like Peter Näher, who turned their resources to the older economic ventures, like working the land, or to newer ones, like extending large "credit lines".$^{58}$ Flexibility and pragmatism were, therefore, typical hallmarks of the Handwerker household. In fact, as argued by Richard Wall, the basic economic unit during the early modern era might best be described as the "adaptive family economy," where the "key characteristic [was] flexibility".59

In Göppingen, arable lands were a crucial component of that flexibility for wealthier households. For instance, when Anna Maria Widmann died in 1770 , the notary recorded that her and her husband's household consisted of not only "a three-story house, with a barn entrance [...]" worth I,60ofl., but also a collection of "fields, gardens, and community plots", which was

56. StAG, B.II.7c, Gewerbe Steuer I823, p. 43 b.

57. StAG, B.II.2.g, Inventuren und Teilungen, 239-11a (1827).

58. Medick, Weben und Überleben, pp. 212-228, and 229-243.

59. Richard Wall, "Work, Welfare and the Family: An Illustration of the Adaptive Family Economy", in L. Bonfield, R. Smith, and K. Wrightson (eds), The World We Have Gained: Histories of Population and Social Structure (Oxford, 1986), p. 265. 
worth $1,430 f .^{60}$ In fact, farmland was apparently a resource that significantly set the middling and wealthy Handwerker apart from the poor ones (see Table 2). Few, if any, of the poorer households owned enough landed property to pursue agriculture; the Handwerker of the lower stratum were lucky if they owned more than a section of a building. Thus, it is not surprising that ownership of other categories related to agricultural production - i.e. produce and livestock - also distinguished the households of the poorer families from those of the other strata in Göppingen (see Table 2).

Renting out space within one's household as an economic strategy would have also remained limited to better-off households. Again, the poorer households simply did not have enough property for empty space. Indeed, the average value of the lower stratum's real estate always paled in comparison to that of the wealthier households in Göppingen (see Table 2). Moreover, as shown in Table 3 , the lower stratum always had a higher percentage of house- and landless members as compared to the other two strata. Therefore, the typical household among the poorer artisans lived in cramped quarters, and in some cases those quarters were not owned by the family which inhabited them. This, in turn, meant that the lower-stratum artisans must have crowded their workshop into their living space, which would have left little room for tenants or subtenants and for journeymen or apprentices, too. For those poor artisans who did own their homes and perhaps some arable land, their real estate was much more than just the cornerstone of their wealth. Oftentimes, it was the whole sum of the lowerstratum family's wealth, constituting close to, if not over, 100 per cent of its net worth (see Table 2). Of course, owning real estate could in itself be an important strategy for lower-stratum households; they could use it as collateral in acquiring loans, as the Endrißs did, or they might use it as a form of insurance against times of severe crisis. However, beyond the residences that housed their businesses, the poorer households possessed few liquid assets. So, if anything went wrong, then the whole kit-and-caboodle could easily be lost. Fettered by this, the industrious households of the lower stratum lacked the versatility that characterized the middling-to-wealthier households in Göppingen.

The poorer artisans did, nonetheless, explore other strategies in an effort to adapt to the changing world around them. The households in the lower stratum tried, like most small-scale producers, to rely on the strategy of reallocating more of their total wealth to their craft tools, supplies, and wares to take advantage of good economic times. But, when it came to the average amount of Gulden allocated to this category (Table 2), the poorer

6o. StAG, B.II.2.g, Inventuren und Teilungen, 16.2-250 (1770). The Widmanns were wealthy tanners, and incidentally this probate inventory, unlike the Vayhingers', categorized the their "community plots" as part of their permanent real estate. The Widmanns presumably had a long-term lease on those plots. 
Table 2. Categories of possessions by stratum (I738-1827)

\begin{tabular}{|c|c|c|c|c|c|c|}
\hline Category & $\begin{array}{c}\text { Lower } \\
\text { Average } \\
\text { value in } \mathrm{Al} .\end{array}$ & $\begin{array}{l}\text { Astratum } \% \text { of } \\
\text { net worth }\end{array}$ & $\begin{array}{c}\text { Middle } S \\
\text { Average } \\
\text { value in } \mathrm{fl} .\end{array}$ & $\begin{array}{l}\text { Stratum } \\
\text { As \% of } \\
\text { net worth }\end{array}$ & $\begin{array}{c}\text { Upper S } \\
\text { Average } \\
\text { value in } f .\end{array}$ & $\begin{array}{l}\text { Astratum } \\
\text { As \% of } \\
\text { net worth }\end{array}$ \\
\hline $\begin{array}{l}\text { Real estate: } \\
\text { Buildings } \\
1738-1767 \\
1768-1797 \\
1798-1827 \\
\text { Arable lands } \\
1738-1767 \\
1768-1797 \\
1798-1827 \\
\end{array}$ & $\begin{array}{r}184.97 \\
237.70 \\
298.70 \\
\\
12.93 \\
13.55 \\
69.02 \\
\end{array}$ & $\begin{array}{r}80.69 \\
92.27 \\
112.91 \\
\\
5.64 \\
5.25 \\
26.09 \\
\end{array}$ & $\begin{array}{r}377.66 \\
676.96 \\
1,024.63 \\
\\
99.17 \\
259.18 \\
256.60 \\
\end{array}$ & $\begin{array}{l}55.93 \\
58.39 \\
63.92 \\
\\
14.69 \\
22.73 \\
16.01 \\
\end{array}$ & $\begin{array}{r}724.62 \\
1,470.48 \\
1,943.22 \\
\\
543.47 \\
964.71 \\
741.81 \\
\end{array}$ & $\begin{array}{l}23.57 \\
34.26 \\
32.37 \\
\\
17.68 \\
22.48 \\
12.36 \\
\end{array}$ \\
\hline $\begin{array}{l}\text { Craft tools, } \\
\text { wares, etc. } \\
1738-1767 \\
1768-1797 \\
1798-1827 \\
\end{array}$ & $\begin{array}{l}10.69 \\
57.94 \\
21.28 \\
\end{array}$ & $\begin{array}{r}4.66 \\
22.47 \\
8.04 \\
\end{array}$ & $\begin{array}{r}19.41 \\
146.26 \\
288.68\end{array}$ & $\begin{array}{r}2.88 \\
12.61 \\
18.01 \\
\end{array}$ & $\begin{array}{l}174.64 \\
293.96 \\
514.00\end{array}$ & $\begin{array}{l}5.75 \\
6.85 \\
8.56 \\
\end{array}$ \\
\hline $\begin{array}{c}\text { Loans extended } \\
1738-1767 \\
1768-1797 \\
1798-1827\end{array}$ & $\begin{array}{l}35.39 \\
17.85 \\
11.64\end{array}$ & $\begin{array}{r}15.44 \\
6.92 \\
4.40\end{array}$ & $\begin{array}{l}124.38 \\
158.61 \\
240.69\end{array}$ & $\begin{array}{l}18.42 \\
13.68 \\
15.01\end{array}$ & $\begin{array}{r}827.24 \\
1,148.71 \\
2,036.13\end{array}$ & $\begin{array}{l}26.91 \\
26.77 \\
33.92\end{array}$ \\
\hline $\begin{array}{r}\text { Debts owed } \\
1738-1767 \\
1768-1797 \\
1798-1827 \\
\end{array}$ & $\begin{array}{l}-112.56 \\
-201.95 \\
-238.40 \\
\end{array}$ & $\begin{array}{l}-49.11 \\
-78.32 \\
-90.11 \\
\end{array}$ & $\begin{array}{l}-159.93 \\
-421.28 \\
-637.52 \\
\end{array}$ & $\begin{array}{l}-23.69 \\
-36.33 \\
-39.77 \\
\end{array}$ & $\begin{array}{l}-198.06 \\
-553.26 \\
-789.38\end{array}$ & $\begin{array}{r}-6.44 \\
-12.89 \\
-13.15\end{array}$ \\
\hline $\begin{array}{l}\text { Cash } \\
1738-1767 \\
1768-1797 \\
1798-1827\end{array}$ & $\begin{array}{r}10.47 \\
13.88 \\
6.89 \\
\end{array}$ & $\begin{array}{l}4.57 \\
5.38 \\
2.61 \\
\end{array}$ & $\begin{array}{l}38.26 \\
47.39 \\
64.07 \\
\end{array}$ & $\begin{array}{l}5.67 \\
4.09 \\
4.00 \\
\end{array}$ & $\begin{array}{l}452.73 \\
273.57 \\
470.46\end{array}$ & $\begin{array}{r}14.73 \\
6.37 \\
7.84 \\
\end{array}$ \\
\hline $\begin{array}{l}\text { Clothing and } \\
\text { jewelry } \\
1738-1767 \\
1768-1797 \\
1798-1827 \\
\end{array}$ & $\begin{array}{l}25.18 \\
36.02 \\
23.36 \\
\end{array}$ & $\begin{array}{r}10.99 \\
13.97 \\
8.83 \\
\end{array}$ & $\begin{array}{l}40.70 \\
81.34 \\
85.72 \\
\end{array}$ & $\begin{array}{l}6.03 \\
7.02 \\
5.35 \\
\end{array}$ & $\begin{array}{r}82.29 \\
124.74 \\
131.98 \\
\end{array}$ & $\begin{array}{l}2.68 \\
2.91 \\
2.20 \\
\end{array}$ \\
\hline $\begin{array}{l}\text { Furniture, } \\
\text { bedding, linens } \\
1738-1767 \\
1768-1797 \\
1798-1827 \\
\end{array}$ & $\begin{array}{l}48.54 \\
58.30 \\
52.73 \\
\end{array}$ & $\begin{array}{l}21.18 \\
22.61 \\
19.93 \\
\end{array}$ & $\begin{array}{r}76.16 \\
113.69 \\
152.27 \\
\end{array}$ & $\begin{array}{r}11.28 \\
9.81 \\
9.50 \\
\end{array}$ & $\begin{array}{l}189.92 \\
212.33 \\
279.76\end{array}$ & $\begin{array}{l}6.18 \\
4.95 \\
4.66 \\
\end{array}$ \\
\hline $\begin{array}{l}\text { Produce and } \\
\text { livestock } \\
\qquad \begin{array}{l}1738-1767 \\
1768-1797 \\
1798-1827\end{array}\end{array}$ & $\begin{array}{l}0.42 \\
0.33 \\
4.52\end{array}$ & $\begin{array}{l}0.18 \\
0.13 \\
1.71\end{array}$ & $\begin{array}{r}7.79 \\
22.83 \\
29.60 \\
\end{array}$ & $\begin{array}{l}1.15 \\
1.97 \\
1.85\end{array}$ & $\begin{array}{r}63.15 \\
96.17 \\
114.74\end{array}$ & $\begin{array}{l}2.05 \\
2.24 \\
1.91\end{array}$ \\
\hline $\begin{array}{l}\text { Household items }^{61} \\
1738-1767 \\
1768-1797 \\
1798-1827\end{array}$ & $\begin{array}{l}10.16 \\
20.14 \\
13.05\end{array}$ & $\begin{array}{l}4.43 \\
7.81 \\
4.93\end{array}$ & $\begin{array}{l}46.64 \\
62.69 \\
93.54\end{array}$ & $\begin{array}{c}6.91 \\
5.41 \\
5.83\end{array}$ & $\begin{array}{l}202.70 \\
252.10 \\
554.94\end{array}$ & $\begin{array}{l}6.59 \\
5.87 \\
9.24\end{array}$ \\
\hline
\end{tabular}


Table 2. continued

\begin{tabular}{|c|c|c|c|c|c|c|}
\hline Category & \multicolumn{2}{|c|}{$\begin{array}{l}\text { Lower Stratum } \\
\text { Average As \% of } \\
\text { value in } f \text {. net worth }\end{array}$} & \multicolumn{2}{|c|}{$\begin{array}{l}\text { Middle Stratum } \\
\text { Average As } \% \text { of } \\
\text { value in } \mathrm{fl} \text {. net worth }\end{array}$} & \multicolumn{2}{|c|}{$\begin{array}{c}\text { Upper Stratum } \\
\text { Average As } \% \text { of } \\
\text { value in } \mathrm{fl} \text {. net worth }\end{array}$} \\
\hline $\begin{array}{l}\text { Books } \\
1738-1767 \\
1768-1797 \\
1798-1827\end{array}$ & $\begin{array}{l}3.04 \\
3.88 \\
1.75\end{array}$ & $\begin{array}{l}1.33 \\
1.50 \\
0.66\end{array}$ & $\begin{array}{l}4.94 \\
7.47 \\
4.80\end{array}$ & $\begin{array}{l}0.73 \\
0.64 \\
0.30\end{array}$ & $\begin{array}{l}9.00 \\
8.09 \\
5.93\end{array}$ & $\begin{array}{l}0.29 \\
0.19 \\
0.10\end{array}$ \\
\hline $\begin{array}{l}\text { Net worth } \\
\text { (sum of categories) } \\
1738-1767 \\
1768-1797 \\
1798-1827\end{array}$ & \multicolumn{2}{|c|}{$\begin{array}{l}229.22 \\
257.84 \\
264.55\end{array}$} & \multicolumn{2}{|c|}{$\begin{array}{r}675.18 \\
1,159.46 \\
1,603.08\end{array}$} & \multicolumn{2}{|c|}{$\begin{array}{l}3,073.69 \\
4,291.62 \\
6,003.59\end{array}$} \\
\hline
\end{tabular}

Sources: StAG, Inventuren und Teilungen

Table 3. Percentage of each stratum without real estate (1738-1827)

\begin{tabular}{l|c|c|c}
\hline Period & Lower stratum & Middle stratum & Upper stratum \\
\hline $1738-1767$ & 17.24 & 8.62 & 3.33 \\
$1768-1797$ & 32.26 & 4.92 & 0.00 \\
$1798-1827$ & 14.81 & 7.41 & 0.00 \\
\hline
\end{tabular}

Sources: StAG, Inventuren and Teilungen

households simply could not keep up with their socioeconomic superiors. While the wealthiest and middling families made steady increases over the course of the ninety years studied, the poorest families increased only between the first and second interval. Simply stated, the rich and middling could afford the costs involved in expanding their small-scale production, whereas the poorer could not. Their poverty, in effect, negated this economic strategy for survival. This forced most of them into an untenable position, where all focus was on a household industry that could not be made competitive when new economic opportunities and pressures arose in the late eighteenth and early nineteenth centuries.

The indefatigable artisans of the lower stratum did, however, seek a way out of this dilemma. One possible course of action was to increase the economic capital available to their industrious households by borrowing more and paying back less. This was most likely the motive behind the 5oofl. grant that the Endrißs applied for in 1803 , and it was clearly the motive behind the Greiners, the shoemakers, who took Ioofl. in leather

6r. This category includes the following items from the probate inventories: brass utensils + tin utensils + copper utensils + iron utensils + tinplate utensils + wooden utensils + barrel and binding materials + common household goods and tools + harness, tack, and building materials + foodstores + supplies + wine and other drinks. 
supplies on credit from two tanners. According to Table 2, a good number of other households hit upon this strategy as the average amount that the lower stratum borrowed continued to outpace the loans that they extended. On the other hand, the families of the upper stratum evidently became the creditors as they continued to loan out more than they borrowed. For many of the poorer households, these increased debt burdens were a logical way to increase their resources, but the overwhelming nature of these debts could also spell doom, as shown above by the cases of the Endriß and Maier households. Ultimately then, the strategy of increasing stagnant resources through enlarged debt burdens was a double-edged sword: one edge may have increased economic viability, but the other introduced even more risk of disaster. Whether conscious or unconscious, this behavior was both cause and effect of the limited flexibility and adaptability found among the poorer households.

The least wealthy families had yet another strategy designed to deal with the changing world around them. Even before they tried to rouse their small-scale production with more fluid capital, the poorer artisans concentrated more of their net worth on items that carried social and cultural capital, rather than just economic capital. Indeed, when it came to noneconomic goods, like clothing, jewelry, furniture, and bedding, the lowerstratum households always devoted to them proportions of their net worth that clearly exceeded the rates of their socioeconomic superiors (see Table 2). To be sure, in absolute values the poorer families did not own as much of these items as the middling and wealthy, but they did keep pace with the new fashions and styles that came with the sartorial revolution of the late eighteenth and early nineteenth centuries. In 1738, for example, the lower-stratum Weißs, who worked as tailors, owned a number of novel items in their rather abundant wardrobes. Justina Weiß had a necklace and a number of colorful skirts and bonnets, and Johannes had a pair of woolen cloth trousers. ${ }^{62}$ The trousers were particularly unusual, for during much of the eighteenth century, leather was the material of choice for trousers among artisan-craftsmen. ${ }^{63}$ Given their trade, though, it would have made good business sense for the Weißs to advertise their wares and craftsmanship in tailoring through their own wardrobes. Justina and Johannes would have been likely "trend-setters", because new trends and fashions create great potential for business among tailors. ${ }^{64}$

All three of the poorer households mentioned above had trendy items among their possessions. The Greiners, who struggled as cobblers during the I770s, owned clothes and jewelry, such as a blue waistcoat, numerous

62. StAG, B.II.2.g, Inventuren und Teilungen, 1.38-109.5 (1738).

63. See Benscheidt, Kleinbürgerlicher Besitz, p. II6; and Ernst Schubert, "Daily Life, Consumption, and Material Culture", in Sheilagh Ogilvie (ed.), Germany: A New Social and Economic History, vol. 2: $1630-1800$ (London, 1996), p. 362.

64. See Medick, Weben und Überleben, p. 419. 
colorful skirts, and a necklace, that did not differ much at all in style and fashion to those of their socioeconomic superiors. Maria Barbara and Georg Adam also owned a "Trisure" [i.e. sideboard], which was considered a luxury item in the 1770 s. $^{65}$ Similarly, the Endrißs had among their possessions a "Seßel" [i.e. easychair], which was still a novelty in 1827 . In their wardrobes could be found the following up-to-date and fashionable items: " $a$ zizene [i.e. colorful lightweight cotton] skirt, a zizene apron, [and] a taffeta apron" for Margaretha; and "silver shoe buckles, silver suspender buckles, woolen worsted trousers [and] a dark blue overcoat" for Johann Georg. ${ }^{66}$ And, lastly, even the elderly turner, Johann David Maier, had among his household possessions in 1827 certain novel furnishings, such as "two nonupholstered Canapee [i.e. sofa/daybed], a Seßsel, two portraits, and a birdcage ${ }^{7}{ }^{67}$ By acquiring a relatively wide array of the latest styles, these households, like many other members of the lower stratum, engaged in the new behavior of keeping in fashion. However, while the middling and wealthy families comfortably acquired the new fashions with little trouble, the least wealthy artisans diverted larger portions of their net worth away from revenuegenerating, economic goods to noneconomic, consumer goods. The poorest households, therefore, paid the highest price as the lure of new fashions snared most families in Göppingen, and in general, contemporaneous authorities and social commentators quickly focused on such negative ramifications. Complaints about the "Kleiderluxus (clothing luxury)" of the petty bourgeois "run through the entire [eighteenth century]" ${ }^{68}$. These writers, according to Helmut Müller, realized that "[w]ith the scanty economic leeway of the Kleinbürgertum, clothing luxury [could have] ruinous consequences". ${ }^{69}$

The lower-stratum artisans in Göppingen, however, may have had good motives for devoting larger portions of their wealth to these goods. They had, as demonstrated by their stagnant wealth, little success in taking advantage of good economic opportunities, whereas their wealthier contemporaries not only grew more wealthy but also acquired the trappings - both in clothing and jewelry and in household furnishings - that signified such wealth. In a situation where they had little flexibility and, hence, could not truly compete economically with their richer and middling colleagues, the lower-stratum households could, at least, acquire the new styles and fashions as soon as, if not sooner than, their colleagues in the upper and middle strata. By adopting the new trends in clothing, jewelry, and furnishings, they made what Bourdieu might consider "an excellent investment in social

65. StAG, B.II.2.g, Inventuren und Teilungen, 19.2-49.5 (1779).

66. StAG, B.II.2.g, Inventuren und Teilungen, 239-12a (1827).

67. StAG, B.II.2.g, Inventuren und Teilungen, 239-1ra (1827).

68. Helmut Möller, Die Kleinbürgerliche Familie im 18. Jabrhundert: Verhalten und Gruppenkultur (Berlin, 1969), p. I43.

69. Ibid., p. 146 . 
capital".$^{70}$ Clothing, after all, served - and continues to serve - as outward expression of one's position in society, and hence, such items carried social utility. Indeed, as argued by Möller, when it came to proclaiming one's identity, "magnificence in clothing was not only the most effective - because it fell on the most eyes and at the same time distinguished one from others but it was also the cheapest compared with other forms of representation"?

Unfortunately for the poorer artisans, though, this strategy could only benefit them and their households superficially. On the surface, their outward appearance would have kept them "competitive" with the more profitable craftspeople, but by consciously or unconsciously utilizing this strategy, these lower-stratum families most likely accelerated the depletion of their already meager resources. When thrust into dire straits, where even finding one's daily bread became a frantic and grave struggle, the only economic benefit that diverse wardrobes and stylish furnishings had was the quick cash that might be generated by liquidating them. But owning relatively large and diverse wardrobes and novel furnishings did not, of course, single-handedly cause the immense difficulties that the lower-stratum artisans experienced during the late eighteenth and early nineteenth centuries. There were other, more momentous events, such as the city-wide fire of I782, and thereafter the crisis years of the Napoleonic period, that were certainly nearer the root cause of their difficulties.

Still, the poorer households continued to persevere. In fact, even though the families of the lower stratum in Göppingen had always lacked the means for establishing a truly flexible, patchwork household economy like the Vayhingers, they nevertheless attempted to carve out more room for maneuver. They aggressively expanded their debt burdens as they continued to allocate significant portions of their wealth to material commodities that carried both social and cultural capital. To be sure, they may not have had much choice in the matter, for if they wished to hold on to their status and their position in society as their economic capital declined, then they had to turn to these means. Even with more loans, though, the investments in economic capital (i.e. equipment, stores, real estate, etc.) could oftentimes be too expensive for the poorer households. Hence, the predetermined choice would have been to continue their concentration on social and cultural capital. There was always the possibility that they may have disdained the novel cultural goods of the late eighteenth and nineteenth centuries, but with the strong communal pressures for and societal expectations of conformity in the German hometowns, charting such a course would have been extraordinarily difficult and potentially disastrous. ${ }^{72}$ Instead, out of a desperate resourcefulness, the poorer craftspeople in Göppingen used the

72. See Mack Walker, German Home Towns (Ithaca, NY, 1971). 
novel cultural goods and growing debt burdens as a kind of last ditch effort to salvage their precarious livelihoods. And, although their precise motivations and reasoning are not self-evident in the inventories, it is nonetheless striking that the least wealthy artisans tried to compensate for their lack of access to economic capital by increasing their fluid capital and by investing in social and cultural capital. Within an economy of scarcity, the poorer households tried to stretch what little flexibility and adaptability that they had by employing not only economic but also social and cultural strategies for survival. 